\section{Dear friends and colleagues}

I was truly humbled and honoured by my election as vice president in 2017. During my term in the office of the president, I will aim to build on the exemplary work of my predecessors, in particular Keertan Dheda. My personal goal is to develop new relationships and strengthen existing ties within the greater African community. As I stated in the first edition of the AJTCCM, 'Africa is a place of dichotomy. Our continent is crippled by the "colliding epidemics" of tuberculosis, HIV and smoking-related diseases, but it is also a place of exceptional beauty and great abundance, with a communal spirit and a considerable amount of hope. The unique challenges of our resource-limited environment require unique and innovative solutions. Africa must, and can, provide solutions to our own health crises.'

We are in the midst of tumultuous times, but with all these challenges come great opportunities, and we must make the most of them. We must join with our colleagues on the continent, and rise to prominence as a centre of great African excellence. As the incoming president of SATS, I thank you for the trust you have placed in me to do this.

\section{Professor Coenraad Koegelenberg}

President: South African Thoracic Society


Council members: July 2019 - July 2021

Prof. C Koegelenberg

Prof. R van Zyl-Smit

Prof. M Wong

Dr G Calligaro

Prof. K Dheda

Dr C Smith

Dr A Vanker

Dr I Schewitz

Mr D Maree

Dr C Verwey

Dr G Tiv

Dr M J Mpe

Prof. R Masekela

Dr B Allwood

Prof. K Dheda

Dr S Maasdorp

Dr A Peter

Dr S A van Blydenstein

Dr C Verwey

Dr M S Abdool-Gaffar

Prof. K Dheda

Prof. C Koegelenberg

Prof. R van Zyl-Smit

Prof. K Dheda

Dr M S Abdool-Gaffar
President

Vice President

Secretary

Treasurer

Past President

Private Practice representative

Paediatric Pulmonology representative

Thoracic Surgery representative

Clinical Technology representative

National Asthma Education Programme representative

University of Limpopo representative

Sefako Makgatho Health Sciences University representative

University of KwaZulu-Natal representative

Stellenbosch University representative

University of Cape Town representative

University of the Free State representative

University of the Witwatersrand representative

Elected members

Editor-in-Chief: African Journal of Thoracic and Critical Care Medicine

Deputy Editor: African Journal of Thoracic and Critical Care Medicine

Chairperson: Scholarship Selection Committee

Credentials Committee

CME Committee 